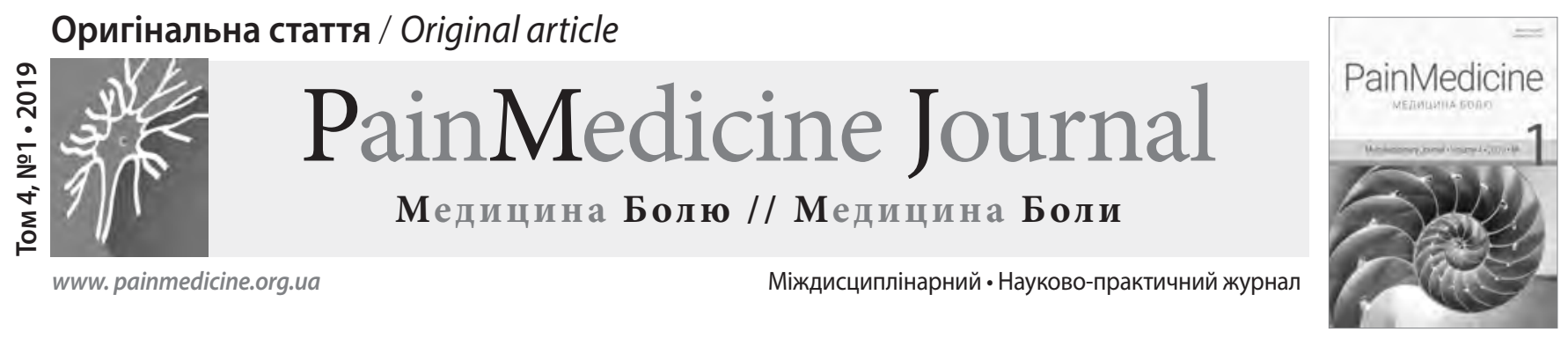

\title{
The Difference Duration between Analgesia Bupivacaine Hy- perbaric Morphine and Bupivacaine Hyperbaric Epinephrine Intrathecal toward Post Surgery of Sectio Caesaria Patient in Bhayangkara Mataram Hospital
}

\author{
Erwin Kresnoadi \\ Faculty of Medicine, Diponegoro University, Indonesia
}

\begin{abstract}
Background and Objectives: The most used of regional anesthesia technic is spinal anesthesia. Spinal anesthesia is an easier technic to get the depth and speed of nerve blockade. Some medicine can be used as an adjuvant of local anesthesia to increase the effect of analgesia bupivacaine. This research is aimed to compare the effectiveness of administration of $0.1 \mathrm{mg}$ intrathecal morphine and $0.1 \mathrm{mg}$ intrathecal epinephrine to prolong $0.5 \%$ $12.5 \mathrm{mg}$ hyperbaric analgesia bupivacaine toward caesarean section postoperative period. Method: This research is an experimental clinical trial randomized double-blind phase II. Subject of this study is the elective surgery patients (ASA I and II) with spinal anesthesia who are 18-40 years old and having weight around 50-70 kgs. There are 48 patients that is divided into 2 groups; 24 patients of group $M$ (morphine $0.1 \mathrm{mg}$ ) and 24 patients of group E (epinephrine $0.1 \mathrm{mg}$ ). Result: The result of this study revealed the duration of analgesia is longer in group M (morphine $0.1 \mathrm{mg}$ ) than group $T$ (tramadol $25 \mathrm{mg}$ ) (309.08 $\pm 5.55 \mathrm{vs} 221.66 \pm 6.43)$. Conclusion: adjuvant of $0.1 \mathrm{mg}$ morphine and $0.5 \% 12.5 \mathrm{mg}$ intrathecal hyperbaric bupivacaine can make the work period of analgesia longer while post caesaria section surgery rather than $0.5 \% 12.5 \mathrm{mg}$ bupivacaine and 0.1 intrathecal epinephrine.
\end{abstract}

Keywords: Spinal anesthesia; bupivacaine; duration of analgesia; morphine; and epinephrine.

\section{Introduction}

Nowadays, regional anesthesia technic that used to be the procedure of surgery considered to be developed. The most used regional anesthesia technic is spinal anesthesia. Spinal anesthesia depicted as an easier technic used to get the depth and speed of nerve blockade [1]. Not only because the affordable cost and small effect of systematic as well as better ability to prevent stress respond, but also important to get the safe and satisfying result [2].
One of local anesthetics medicines used is bupivacaine. Bupivacaine is local anesthesia medicine that is categorized as amid with the formula of 2-piperidine carbonamide, 1 butyl (2,6-dimethylphenol) monochloride. Bupivacaine has a long duration with more sensory blockade than motor. Some medicine can be used as adjuvant local anesthesia to increase the effect of analgesia bupivacaine. These are medicine that categorized as opioid and adrenergic [3]. 
Systemic opioid is effective to control the pain while surgery occurred and post-surgery [4]. Then, intrathecal morphine is the most effective analgesia used while post-surgery [5]. The combination of morphine and bupivacaine can increase the effect of analgesia from morphine by changing opioid binding place to spinal receptors [6]. The effective impact of analgesia can be obtained by $0.1-2.5 \mathrm{mg}$ dose. In the past years, the interval dose of $0.1-0.25 \mathrm{mg}$ has already used to reduce the side effect and complication. The combination of the low dose of intrathecal morphine and spinal anesthesia give the effective and analgesia effect after surgery occurred [7].

Epinephrine is a medicine that produces vasoconstricts on the injection area, hence it can reduce the absorption level of blood flow and will prolong the duration of local anesthesia effect. The effect of giving epinephrine as adjuvant anesthetics medicine is having anti-nociceptive that is mediated by the activation of $\alpha_{2}$-adrenoreseptor on gelatinase substantial in spinal cord [8]. Concomitant distribution of $0.12 \mathrm{mg}$ epinephrine intrathecally to $0.5 \% 12.5 \mathrm{mg}$ bupivacaine showed prolonged time to the effect of analgesia and the decrease of additional analgesia injection area number [9].

\section{Literature review}

\subsection{Bupivacaine}

Bupivacaine is local anesthetics that categorized as amid with long work period [10]. Bupivacaine has a chemical formula as follows:

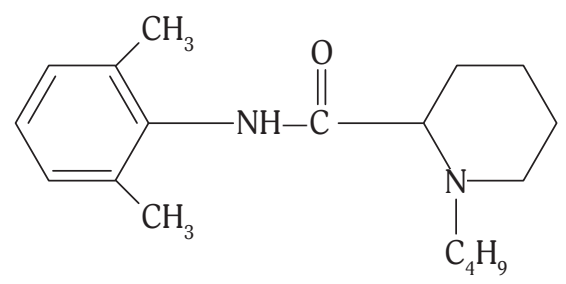

(RS)-1-butyl-N-(2,6-dimethylphenyl)piperidecarboxamide-hydrochloride

Fig. 1. Bupivacaine Chemical Formula [11]

Bupivacaine is mepivacaine butyl derivative which is approximately three times stronger than its origin. According to Molnar [12], bupivacaine is available in $5 \mathrm{mg} / \mathrm{ml} \mathrm{prepa-}$ ration. The impact tends to obstructer sensory block than motor block caused by this medicine which is often used for analgesia while surgery and post-surgery [13]. Bupivacaine is available in isobaric or hyperbaric form. Commonly, isobaric bupivacaine is used $0.5 \%$ concentration with volume $3-4 \mathrm{ml}$ and total doses 15-20 mg, however, hyperbaric bupivacaine is used $0.5 \%$ concentrate with volume $2-4 \mathrm{ml}$ and total doses 15-22.5 mg. Besides the long work period of this anesthetics, bupivacaine has low motor blockade [14]. According to Jeffry et al (2013), 0.5\% isobaric of local anesthetics used will longer produce sensory blockade and blood flow and pressure will be stable than $0.5 \%$ hyperbaric bupivacaine. The used of $0.5 \%$ isobaric bupivacaine can be considered as surgery procedure with longer work period that is more than 2 hours because it has a stable effect of hemodynamic changes if it is compared to the used of hyperbaric bupivacaine. Thus, it recommended for the patient who has the ability of hemodynamic compensation that is not good enough [15].

\subsubsection{Bupivacaine Pharmacology}

Bupivacaine works to make neuron membrane stable by obstructing the change of ionic continually which is needed to start and deliver impulse. The sophisticated knowledge of anesthetics which related to diameter, myelinization, and the speed of delivery of the affective nerve fibers that showed the following sequence of function loss: autonomic, pain, temperature, touch, proprioception, and skeletal muscle tonus [14]. Bupivacaine elimination occurred in liver and through breathing (lungs).

\subsubsection{The Spread of Local Anesthetics in the Subarachnoid Space}

The spread of local anesthetics in subarachnoid space are influenced by several factors such as: age, patient height, injection area, volume of liquor cerebra spinalis, injection speed: barbotage, baristas, dose, and volume of local anesthetics medicine $[11,16]$.

\subsubsection{Pharmacokinetic of Local Anesthetics in the Subarachnoid Space}

Local anesthetics medicine has immediately affected after subarachnoid injection. The effect reduced the concentration step by step because of dilution and liquor cerebra spinalis mix, diffusion and distribution of nerve system, uptake, and fixation by nerve system, absorption, and elimination of blood vessel [16]. This medicine will contact nerve system and blockade the impulse transmit ion of nerve fibers in subarachnoid area. The long of subarachnoid analgesia depends on some factors, the first is anesthetics local concentration in liquor cerebra spinalis and the second is absorption of anesthetics medicine by vascular system. The greater concentration longer the effect of analgesic. Analgesic concentration would reduce based on part-time due to the distance from the place which have the greatest concentration, and clinically there will be an analgesic regression from top to bottom towards the greatest concentration area $[12,16]$.

Assessment of long work period of subarachnoid block local anesthesia can be performed in various ways: loss time of the first postoperative analgesic effect, time required for analgesic regression in 2 or 4 segments [11]. The two-segment regression time is needed to decrease the sensory level by two levels of dermatomes [17]. 


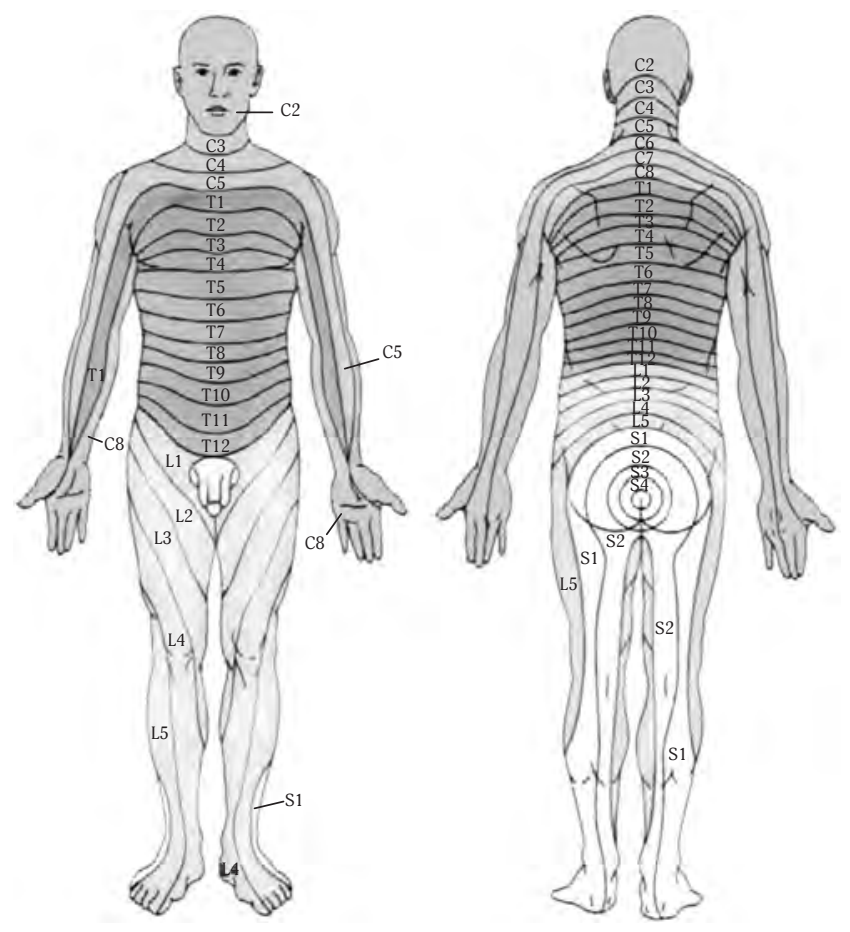

Fig. 2. Dermatomes (www.healthpages.org)

\subsection{Morphine}

Morphine is an important alkaloid from opium which has chemical formula as below:

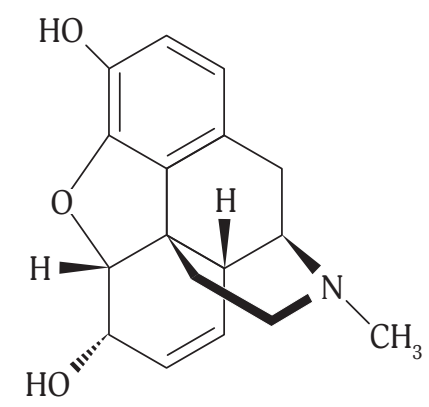

Fig. 3. Morphine Chemical Formula [11]

Morphine is described as opioid receptor agonies with main effect is binding and activating the $\mu$-opioid receptor and central nervous system. Receptor activation is connected to the analgesia. Morphine is also as receptor $\kappa$-opioid agonies that is connected to spinal analgesia. Basically, the effect of morphine analgesia based on 3 mechanism: (1) morphine raises the pain threshold; (2) morphine can affect emotions, means that morphine can change the reaction that arise in the cerebral cortex when pain perception is received by the cerebral cortex of the thalamus; (3) morphine facilitates sleep and at the bedtime, the pain threshold increases [18].

\subsection{Epinephrine}

Epinephrine is adrenergic medicine which has chemical formula as below:<smiles>CNC[C@H](O)c1ccc(O)c(O)c1</smiles>

Fig. 4. Epinephrine Chemical Formula [11]

Epinephrine characters are difficult to dissolve in water, insoluble in ethanol (95\%) and in ether, soluble in ammonia solution and in alkali carbonate, unstable in alkali or neutral [19].

Epinephrine has an effect in all of adrenergic receptor such as $\alpha_{1}, \alpha_{2}, \beta_{1}$. The most prominent effect is epinephrine effect against heart, vascular smooth muscle, and other smooth muscles. Epinephrine has several functions such as quickly overcome the hypersensitivity reactions, including anaphylaxis because epinephrine works as a vasoconstrictor and bronchodilator. Besides that, epinephrine is also used to prolong the work period of local anesthesia by reducing the local blood flow, so that it can extend the duration of local anesthetics effects [20]. Epinephrine is a direct adrenergic medicine because epinephrine immediately works to form a complex with adrenergic receptor. Epinephrine has quickly onset but faster duration. In order to get quickly onset, subcutes, endotracheal pipe, inhalation, or topical of eye are necessary to be given. The used of peroral is not effective, because epinephrine can be destroyed by enzyme in intestine.

The used of $0.9 \mathrm{mg}$ epinephrine to $0.5 \% 12.5 \mathrm{mg}$ bupivacaine has an analgesia effect which adequate post-surgery as well as reducing diaphragm paralysis incident [21]. Besides that, the extension of the analgesia effect was also found intrathecally in the use of sufentanil by adding epinephrine $(200 \mu \mathrm{g})$ to show prolonged analgesia in pot-orthopedic patient [22]. The concomitant administration of $0.12 \mathrm{mg}$ epinephrine to $0.5 \% 12.5 \mathrm{mg}$ bupivacaine showed the prolonged time of analgesia effect and the decrease of the number of additional analgesia injections [9]. Epinephrine is chosen as adjuvant of local anesthesia medicine because it has not cause nausea, pruritus, and respiratory depression. Epinephrine can be as potent analgesia if it is given intrathecally [22].

\subsection{Pain Pathophysiology}

\subsubsection{Pain Physiology}

According to the definition, pain is a protection mechanism that can raise the awareness of interference or the 
network damage [23]. Pain receptor is free nerve endings or referred to as nociceptors which are widely spread on the surface of the skin and certain network such as the periosteum, arterial wall, joint surface, and the tentorium of the cranium [24]. Nociceptor only responds to the stimulus or stimulation that is very potential to cause a damaged network. This case is the first step in the process of causing pain sensations [25].

Based on the types, pain is categorized as nociceptive, somatic pain, visceral pain, neuropathic pain, and psychogenic pain. Those types have a pain quality and different pain modulates because of the place and pain stimulus that was given [25]. Nociceptive pain itself is a pain that cause of the stimulation in the nociceptor either by mechanically, thermally, or chemically stimulation that often to be caused of allogenic substances. Allogenic substance is substance that is released by damaged network or subcutaneous injection from the outside such as histamine, serotonin, bradykinin, $\mathrm{P}, \mathrm{K}^{+}$substance, and prostaglandins.

\section{Pain Mechanism}

Based on the mechanism, pain involved the perception as well as the response against the pain itself. Pain mechanism consists of 4 process as follows:

\section{Transduction.}

Transduction is a pain stimulation process that is converted to the form which can be accessed by brain. Transduction is started by the activation of nociceptor which the receptor receives the activated pain stimulation. The activation of nociceptor is a response against the stimulus such as network damaged [26].

\section{Transmission.}

Transmission is a series of neural events that carry the electrical impulses through the nervous system to the area of the brain. This process involved afferent nerve which if formed by small to medium diameter and large diameter nerve fibers [13]. Nerve smooth fibers of A $\delta$ melted with a speed of up to $30 \mathrm{~m} / \mathrm{s}$ (fast fibers) and $\mathrm{C}$ nerve fibers that is not melted with lower speed of about $12 \mathrm{~m} / \mathrm{s}$ (slow fibers) [23]. Afferent fiber will axon to dorsal horn in the spinalis. After that, this transmission is continued through the spinothalamic contralateral system and lateral ventral from thalamus to cerebral cortex [27].

\section{Modulation.}

Modulation process involved the complexity of neural system. Modulated started from pain impulse to the central nerve. This pain impulse transmission would be controlled by central nerve system and transmitting to another section of nerve system such as cortex. Then, pain transmission will be continued through the descend nerve to spine for modulating effectors.

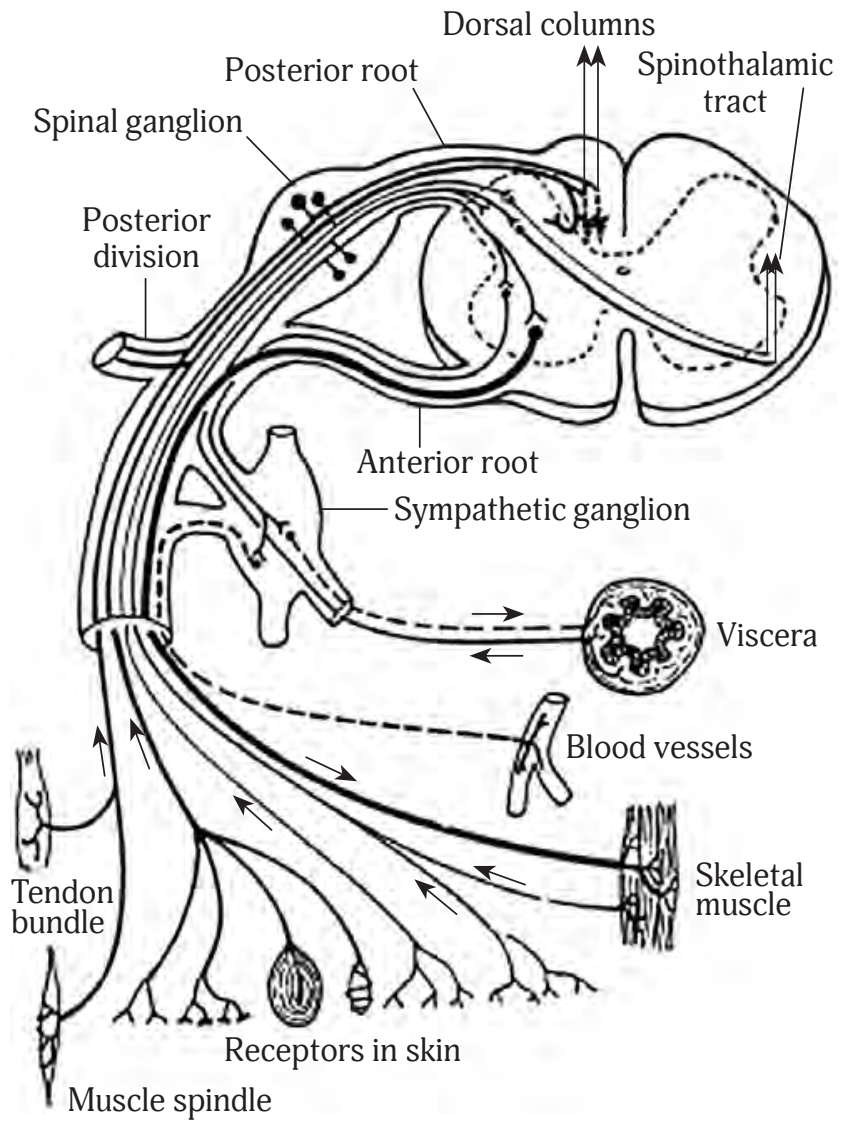

Fig. 5. Representative Scheme of nociceptive modulation in Horn Dorsalis [3]

\section{Perception.}

Perception is a conscious state of expression that is located in the higher cortex. The brain may be a transmitted signal filter, mainly influenced by cognitive factors and behavioral factors that can modify pain. Another factor that influences the occurrence of perception such as relaxation, meditation, and mental disposition can reduce pain perception by limiting the signal process to the pain stimulus [3].

\subsubsection{Pain Classification}

Pain can be classified based on place, the severity of the pain, characteristic, and attack timing.

\section{Place.}

According to the place, pain felt peripheral pain in the body surface that can raise by stimulation such as temperature, chemical, mechanic, or electric [28]. Deep pain is the deeper body surface pain or commonly called as somatic pain or visceral pain that is difficult to determine the location. Somatic pain comes from tendon, ligamentum, muscle, joint, bond, and artery [28]. Referred pain is caused of organ disease or the different system inside the body, not from the origin of the pain thus can 
be referred as a deep pain [28]. The next pain is central pain. It is a pain that caused of the stimulation on the central nerve system, brain stem, thalamus, spinal cord, etc. [28].

2. Characteristics.

According to the characteristics, incidental pain is a pain that can be occurred at any time the disappeared [29]. Steady pain is a pain that arises the settles and is felt for a long time [29]. Another pain is proximal pain is a pain that arise with high intensity and very strong. It settles about 10-15 minutes then arise again.

\section{Attack Timing.}

According to the timing attack, pain can include acute pain that has sudden onset and lasts a short time (less than 6 months) and disappears when the factors that stimulate the pain are eliminated. Besides that, chronic pain is pain that persists for 6 months or more and is often associated with causes or physical injury [28].

\subsubsection{Pain Blockade}

The principle of management of pain is blocking or reducing the pain stimulant impulses both peripherally (locally) or central. This effect is an anti-pain or anti-nociception effect known as analgesic properties. This management consists of non-pharmacological namely in the form of stimulus therapy that used Transcutaneous Electrical Nerve Stimulation (TENS), or psychological intervention and pharmacological therapy [3].

There are some ways to obstruct the pain psychologically, physiology, and the used of medicines. There are several substantial that pharmacologically can be used as analgesic to reduce the pain for conscious patients without causing a decrease in total memory as in general anesthesia [30].

One of pharmacology substances that can be used as analgesia is adrenergic such as epinephrine. Epinephrine works by inhibiting pain signals in $\alpha_{2}$ adrenoreceptors, thus it can inhibit the pain transmission.

Opioid works by those ways because opioid receptor pair with $G$ proteins that directly affect $\mathrm{K}$ and $\mathrm{Ca}$. In the normal situation, $\mathrm{G}$ proteins that has GDP (Guanosine Diphosphate) which bound the sub unit of $\alpha, \beta$, and $\gamma$ is in the rest mode (inactive). While opioid interacted with its receptor, sub unit GDP dissociates and changes into GTP (Guanosine Triphospate) with the mechanism of conformational change. GTP will dissociate with the submit $a$ so that it is bound to it. GTP and sub unit $a$ will instruct nerve cells to reduce their electrical activities to increase the input $\mathrm{K}$ or inhibit $\mathrm{Ca}$. Both of these will reduce nerve electrical activity and decrease the release of neurotransmitters [31].

\section{Conceptual framework}

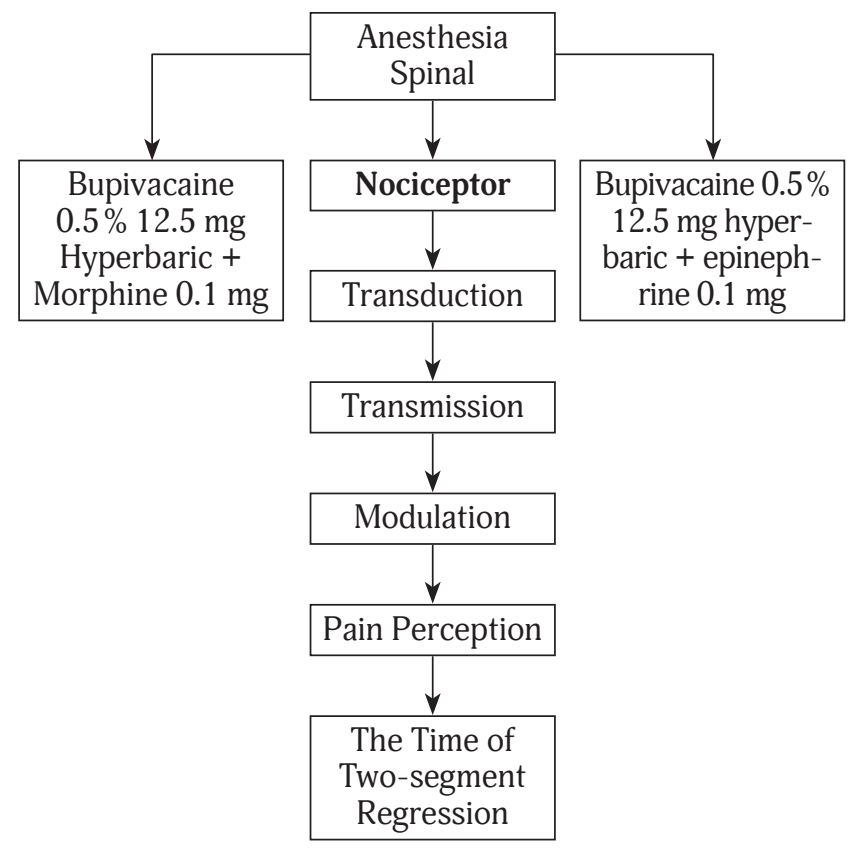

Fig. 6. Research Design

\section{Research method}

\subsection{Research Design}

This research is an experimental clinical trial randomized double-blind phase II. The aim of this study is to know whether $0.1 \mathrm{mg}$ morphine or $0.1 \mathrm{mg}$ epinephrine intrathecal to $0.5 \% 12.5 \mathrm{mg}$ bupivacaine hyperbaric is able to prolong the analgesia post section caesaria surgery.

\subsection{Scoop of the Research}

\subsubsection{Subject of the Research}

All patients that will do effective section caesaria surgery used anesthesia spinal.

\subsubsection{Duration and Place of Research}

Duration: 16 weeks.

Place: Central Surgery Installation of Bhayangkara Mataram Hospital.

\subsubsection{Population of Research}

All patients that will do effective section caesaria surgery used anesthesia spinal in Bhayangkara Hospital.

\subsubsection{How to Choose and Sample Size}

Sample was chosen by using quota sampling to the patients that would perform surgery who are 18-40 years old. $\mathrm{Pa}-$ tients who fulfilled on the criteria and being the samples is the patients who were willing to be volunteers were marked by agreeing to the previously informed consent submitted. 


\section{Inclusion Criteria:}

1. Patients that will do effective section caesaria surgery used anesthesia.

2. ASA I-II physically status.

3. 18-40 years old.

4. Weight of $50-70 \mathrm{kgs}$.

5. Height of $150-170 \mathrm{~cm}$.

6. Duration is less than 2 hours.

7. Agreeing the informed consent.

\section{Exclusion Criteria:}

1. Allergy to drugs used during the study, either bupivacaine, morphine, or epinephrine.

2. Patients who require additional analgesia during surgery.

3. Uncooperative patients.

\section{Sample Size of the Research}

In order to determine the sample size of this research (used 3 pair of groups) statistically used formula as follows:

$$
\mathrm{N} 1=\mathrm{N} 2=\left[\frac{Z \alpha+Z \beta x S d}{d}\right]^{2}
$$

\section{Information:}

$\mathrm{N}=$ Total Sample

$\mathrm{Sd}=$ Standard intersection estimate $=0.15$ (clinical judgement)

$\mathrm{D}=$ Difference in average between the two groups $=0.1$ (clinical judgement)

$\mathrm{a}=$ Significance level (type I error rate) $=5 \%, \mathrm{Z} \alpha=1.960$

$\beta=$ Error level (type II error rate) $=10 \%, Z \beta=1282$ (research power $=90 \%$ )

Based on the calculation results obtained the total samples is $\mathrm{N}=23.65$ people who are necessary to be samples in this study, where total sample is 48 people who are divided into two groups, each consists of 24 people. It consists of:

- Group M (Morphine) numbered 24 people;

- Group E (Epinephrine) numbered 24 people.

Operational Definition:

1. The additional of $0.1 \mathrm{mg}$ morphine that was given simultaneously with $0.5 \% 12.5 \mathrm{mg}$ hyperbaric bupivacaine into the subarachnoid space, the injection speed of 1 $\mathrm{ml} / 5$ seconds drugs without barbotage.

2. The additional of $0.1 \mathrm{mg}$ epinephrine that was given simultaneously with $0.5 \% 12.5 \mathrm{mg}$ hyperbaric bupivacaine into the subarachnoid space, the injection speed of 1 $\mathrm{ml} / 5$ seconds drugs without barbotage.

3. Counting the time was started if the injection was finished to be done in subarachnoid space.

4. Analgesia level is determined based on the dermatome by pinprick, using a $22 \mathrm{G}$ needle of low level. Block height tests were performed by right and left pinprick on the clavicular medial line with a time interval of every $2-10$ minutes.
5. Assessment of motor blocks used Bromiage criteria. The start of motor block work is recorded while the BS Bromiage has scores 3 and the value of motor block loss is $\mathrm{BS} \leq 2$.

6. ASA in extension of the American society of Anesthesiologist which is a classification of physical status that is used as a reference for both surgical procedure and others.

- ASA I: Patient is in the normal condition and healthy without a systematic disease;

- ASA II: Patient is in the mild to moderate systematic disease.

\subsection{Research Framework}

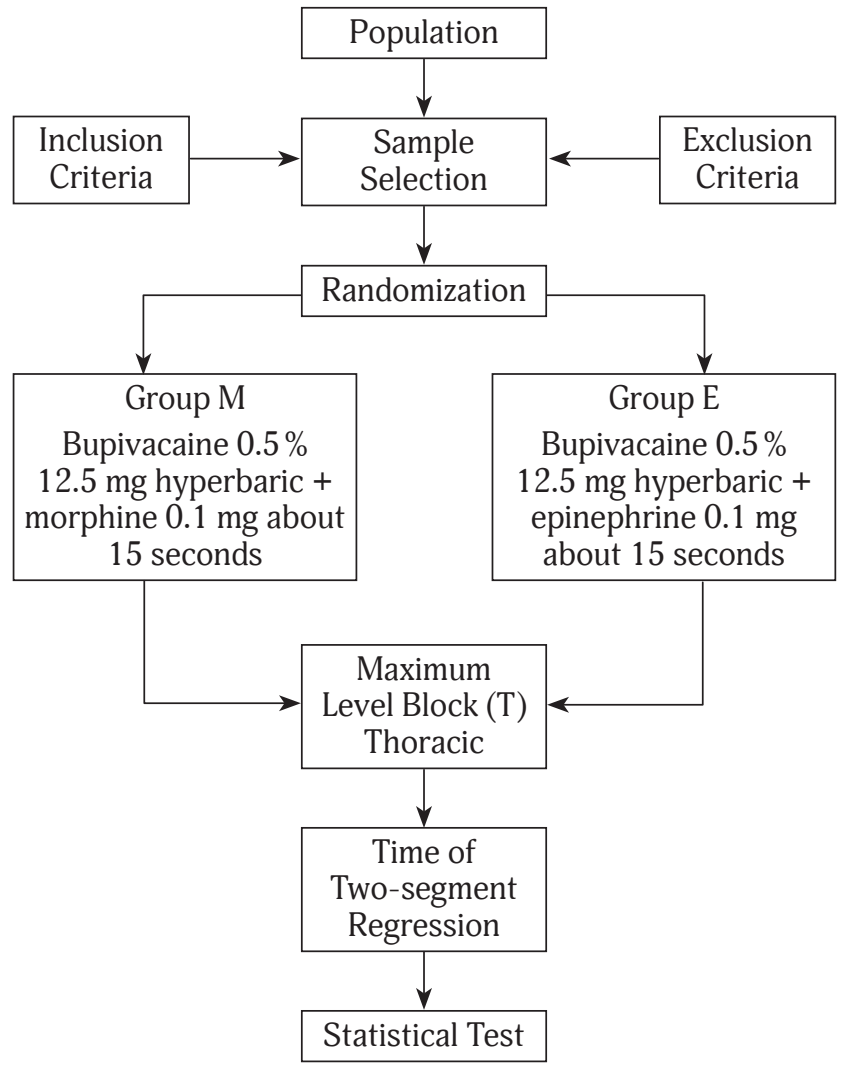

Fig. 7. Research Framework

\subsubsection{Procedures}

Patient was selected while pre-surgery visitation. Patient who fulfilled the criteria was involving as samples. This research was conducted by 48 patients who previously getting the explanation and agreeing to follow the research procedures. They have to check their blood pressure, heart rate, and breathing rate while they were in a room. All patients have to fasting for 6 hours and are not be given premedication drug. They used to infuse while in the Central Surgery Installation with an $18 \mathrm{G}$ intravenous catheter, and preloaded fluid with a 500-cc crystalloid solution. Patients are grouped 
randomly into 2 groups. Each patient has been prepared with a sealed envelope with a specific code containing the local anesthetics drug and the adjuvant. Injections will be carried out by an anesthesiologist.

Instrument and Substances:

1. $0.5 \%$ Bupivacaine Hyperbaric.

2. Spinel needle number $27 \mathrm{G}$.

3. Morphine $\mathrm{HCl}$.

4. Epinephrine $\mathrm{HCl}$.

5. Spit 3 cc Sterile.

\subsection{Data Collection}

Time of two-segment regression, blood pressure, TAR, duration of motor block, heart rate, and side effect were recorded for statistic calculation. Data was written on a particular research sheet that has been provided with one sheet for each patient and separated between the control and treatment groups.

\subsection{Data Analysis}

Data was analyzed and determined as the mean standard intersection (mean $=\mathrm{SD}$ ) and analyzed further by using
SPSS 17 software. Statistical test was conducted to compare between 2 groups that used t-test and significance level $p<0.05$. Statistical result would be presented in table form.

\section{Result and discussion}

\subsection{Result}

The research has been conducted to 48 patients who have already performed caesaria section elective surgery in Bhayangkara Hospital. Patients were divided into two groups; group M consists of 24 patients who have been given intrathecally $0.5 \% 12.5 \mathrm{mg}$ hyperbaric bupivacaine and $0.1 \mathrm{mg}$ morphine for 15 seconds and Group E consists of 24 patients who have been given intrathecally $0.5 \% 12.5 \mathrm{mg}$ hyperbaric bupivacaine and $0.1 \mathrm{mg}$ epinephrine for 15 seconds.

At first, the patient identity was recorded included age, education, gender, type of surgery, physical status (ASA), height (TB), and weight (BB). The examination that was done before and after surgery include systolic blood pressure (TDD), mean arterial pressure (TAR), heart rate, and breathing rate. There are several things that are considered in each patient after administration of anesthetics drugs such

Table 1. Distribution of Patient Characteristic between Two Groups

\begin{tabular}{|c|c|c|c|}
\hline Variables & Control Group $(n=24)$ & Treatment Group $(n=24)$ & $\mathrm{P}$ \\
\hline \multicolumn{4}{|l|}{ Education (\%) } \\
\hline Elementary School & $5(20.84)$ & $5(20.84)$ & \\
\hline Junior High School & $11(45.83)$ & $10(41.66)$ & $0.836^{*}$ \\
\hline Senior High School & $7(29.17)$ & $6(25)$ & \\
\hline Diploma & 0 & $1(4.16)$ & \\
\hline Bachelor & $1(4.16)$ & $2(8.34)$ & \\
\hline Physical Status/ ASA (\%) & & & $0.443^{*}$ \\
\hline ASA I & $19(79.16)$ & $21(87.5)$ & \\
\hline ASA II & $5(20.84)$ & $3(12.5)$ & \\
\hline Age & $25.46 \pm 11.34$ & $27.79 \pm 11.30$ & $0.479 * *$ \\
\hline Height $(\mathrm{cm})$ & $156.21 \pm 2.84$ & $159.50 \pm 5.75$ & $0.825^{* *}$ \\
\hline Weight (kg) & $70.25 \pm 5.85$ & $71.42 \pm 6.04$ & $0.500^{* *}$ \\
\hline TDS (mmHg) & $126.33 \pm 5.32$ & $128.67 \pm 5.70$ & $0.150^{* *}$ \\
\hline $\mathrm{TDD}(\mathrm{mmHg})$ & $81.75 \pm 3.50$ & $83.75 \pm 3.71$ & $0.061^{* *}$ \\
\hline TAR (mmHg) & $96.38 \pm 3.92$ & $98.13 \pm 5.03$ & $0.186^{* *}$ \\
\hline Heart Rate (x/minute) & $87.25 \pm 4.63$ & $85.96 \pm 2.83$ & $0.250^{* *}$ \\
\hline Breathing Rate (x/minute) & $23.00 \pm 0.83$ & $24.00 \pm 0.83$ & $1.000^{* *}$ \\
\hline
\end{tabular}


as sensory block start, maximum thoracic level (T), duration of analgesia, motor block start, motor block duration, and possible side effects in patients after administration of the medicine.

According to the result, it can be listed in the table to compare two groups (A and B). This research used Mann Whitney test to nominal data which included education and physical status (ASA) as well as Independent T-test to numeric data which included age, height (TB), weight (BB), systolic blood pressure (TDD), mean arterial pressure (TAR), heart rate, and breathing rate.

Duration comparation of analgesia between two groups showed that Group M $(309.08 \pm 5.55)$ was longer than Group E (221.21 \pm 4.31$)$. Mann Whitney Test Result was obtained the value of $p<0.05$ which statistically significant.

Side effect was found in Group $\mathrm{M}$ where the number of patients who have nausea are 3 person (12.5) and vomit 1 person (4.1). The rest of patients was fine. However, Group E is totally fine without getting a side effect.

\subsection{Discussion}

The used of spinal anesthesia is an action to give local anesthesia in a particular number in the subarachnoid space to get sensory, motor, and autonomy block nerve. One of the most used local anesthetic drugs is bupivacaine. Bupivacaine is local anesthetic drug that has work period and blockade effect toward sensory greater than motor blockade. The work long period of bupivacaine is $90-120$ minutes, thus it has possibility to use this drug in one injection. Bupivacaine is chosen because the onset of work and the fast period of recovering, relatively easy, and good quality of sensory and motor blockade. Local anesthetic drugs such as bupivacaine required an additional or adjuvant drug to optimize the analgesia effect. One of adjuvants that can be used is opioid.
This research compared two groups namely Group M (Morphine) and Group E (Epinephrine) to do elective caesaria section surgery in Bhayangkara Hospital. According to the statistical result, the common characteristic of research samples between two groups can be seen by knowing the age, education, physical status, height, weight, systolic blood pressure, diastolic blood pressure, mean artery pressure, heart rate, and breathing rate that were significantly different ( $p>0.05$; Table 1$)$. Therefore, those two groups are compatible to be compared.

This research was conducted to 48 samples by comparing the duration of analgesia with the use of $0.5 \% 12.5 \mathrm{mg}$ hyperbaric bupivacaine and 0.1 morphine and $0.5 \% 12.5 \mathrm{mg}$ hyperbaric bupivacaine and $0.1 \mathrm{mg}$ intrathecal epinephrine. It showed that the value of analgesia and the standard average value \pm deviation standard to Group M is $309.08 \pm 5.55$ minutes and Group $E$ is $221.66 \pm 6.43$ minutes. It can be seen that the duration of analgesia in the Group M (morphine) is longer than group E (epinephrine). Mann Whitney test is showed that value of $p<0.05$ statistically significant (Table 2 ).

The use of intrathecal opioid was considered to cause nausea and vomit. Tejwani, G. A. et al explained that the use of intrathecal morphine more often causes nausea and vomit. The research result indicated that the used of $0.1 \mathrm{mg}$ morphine as a combination spinal anesthesia for undergoing patients showed that 3 person experiencing nausea and 1 person experiencing vomit. These results are same as the theory about the idiocy Cron effect of drugs, where each individual has a different response to the side effect of the same medicine. This research was also supported by previous research of Bachmann, where the addition of morphine to bupivacaine showed that the results of 7 nausea and 5 vomited compared to bupivacaine without morphine as adjuvant.

Table 2. Duration Comparation of Analgesia between Two Groups

\begin{tabular}{lccc}
\multicolumn{1}{c}{ Variable } & $\begin{array}{c}\text { Group M } \\
\text { Mean } \pm \text { SD }(\mathrm{n}=24)\end{array}$ & $\begin{array}{c}\text { Group E } \\
\text { Mean } \pm \text { SD }(\mathrm{n}=24)\end{array}$ & P \\
\hline Analgesia Duration (minute) & $309.08 \pm 5.55$ & $221.66 \pm 6.43$ & $0.000^{*}$ \\
* Mann-Whitney Test & & &
\end{tabular}

Table 3. Distribution of Side Effect between Two Groups

\begin{tabular}{|c|c|c|}
\hline Variable & Group M $(n=24)$ & Group $E(n=24)$ \\
\hline \multicolumn{3}{|l|}{ Side Effect (\%) } \\
\hline Nothing & $20(83.4)$ & $24(100)$ \\
\hline Nausea & $3(12.5)$ & 0 \\
\hline Vomit & $1(4.1)$ & 0 \\
\hline
\end{tabular}


Epinephrine can constrict blood vessels and control perfusion, slow the absorption of local anesthetics, hence, plasma levels are also low and minimizing the risk of local anesthetic toxicity due to lower levels of the drug in plasma. Epinephrine also works directly to from complexes with adrenergic receptor. Epinephrine is chosen because it can extend the work period of local anesthetic by reducing local blood flow, so that it can extend the duration of local anesthetics effect. Besides that, epinephrine does not cause nausea, pruritus, and respiratory depression.

This research revealed that adjuvant of $0.1 \mathrm{mg}$ morphine to bupivacaine can make the work period of analgesia bupivacaine longer than $0.1 \mathrm{mg}$ epinephrine.

\section{Conclusion and suggestion}

\subsection{Conclusion}

Based on the research result that has already been conducted, it can be concluded that adjuvant of $0.1 \mathrm{mg}$ morphine and $0.5 \% 12.5$ intrathecal hyperbaric bupivacaine can make the work period of analgesia longer while post caesaria section surgery rather than $0.5 \% 12.5 \mathrm{mg}$ bupivacaine and 0.1 intrathecal epinephrine.

\subsection{Suggestion}

1. Morphine can be used as the one of adjuvant drugs of spinal anesthetic.

2. It is necessary to conduct further research by using the different method and dose.

\section{References}

1. Di Cianni S, Rossi M, Casati A, Cocco C, Fanelli G. Spinal anesthesia: an evergreen technique. Acta Biomed. 2008 Apr;79(1):9-17.

2. Duke, J. Anesthesia Secrets. (2nd ed.). Philadelphia: Mosby-Elsevier; 2006.

3. Dipiro, JT. Pharmacotherapy: A Pathophysiologic Approach. (6th ed.). New York: McGraw-Hill Publishing Co; 2005. p. 1 089-95.

4. Machino M, Yukawa Y, Hida T, Oka Y, Terashima T, Kinoshita S, et al. A prospective randomized study for postoperative pain relief of lower extremity fractures: efficacy of intrathecal morphine administration. Nagoya J Med Sci. 2010 Aug;72(3-4):145-50.

5. Gehling M, Tryba M. Risks and side-effects of intrathecal morphine combined with spinal anaesthesia: a meta-analysis. Anaesthesia [Internet]. Wiley; 2009 Jun;64(6):643-51. Available from: https://doi. org/10.1111/j.1365-2044.2008.05817.x

6. E. M, R. A, M. W, A. T. Rattan: The decline of a once-important non-timber forest product in Indonesia. Center for International Forestry Research (CIFOR); 2014; Available from: https://doi. org/10.17528/cifor/004484

7. Gewirtz D. A critical evaluation of the mechanisms of action proposed for the antitumor effects of the anthracycline antibiotics adriamycin and daunorubicin. Biochemical Pharmacology [Internet]. Elsevier BV; 1999 Apr;57(7):727-41. Available from: https://doi. org/10.1016/s0006-2952(98)00307-4

8. Zeinab R, Abedi MR, Schaufeli WB. Dose interest predicts academic burnout?. Interdisciplinary journal of contemporary research in business. 2012;3(9): 877-885.
9. Goyagi T, Nishikawa T. The Addition of Epinephrine Enhances Postoperative Analgesia by Intrathecal Morphine. Anesthesia \& Analgesia [Internet]. Ovid Technologies (Wolters Kluwer Health); 1995 Sep;81(3):508-13. Available from: https://doi. org/10.1097/00000539-199509000-00014

10. Akhmad Fithrah B, Fuadi I, Rahardjo S, Bisri T, et al. Tatalaksana Anestesi pada Bedah Minimal Invasif Deep Brain Stimulation (DBS). Jurnal Neuroanestesi Indonesia [Internet]. Indonesia Society of Neuroanesthesia and Critical Care (INA-SNACC); 2017;6(2):11423. Available from: https://doi.org/10.24244/jni.vol6no2.137

11. Katzung B, Masters S, Trevor A. Basic and Clinical Pharmacology. (11th ed.). New York: McGraw-Hill Medical; 2009.

12. Levine, W.C, Allain, R.M, Alston, T.A. Clinical Anesthesia Procedures of the Massachusetts General Hospital. (8th ed.). Philadelphia: LWW; 2010. p. 728.

13. Handy JM. Current Anaesthesia \& Critical Care [Internet]. Elsevier BV; 2005 Jan;16(6):403. Available from: https://doi.org/10.1016/j. cacc.2006.02.006

14. TUOMINEN M, KALSO E, ROSENBERG PH. EFFECTS OF POSTURE ON THE SPREAD OF SPINAL ANAESTHESIA WITH ISOBARIC $0.75 \%$ OR $0.5 \%$ BUPIVACAINE. British Journal of Anaesthesia [Internet]. Elsevier BV; 1982 Mar;54(3):313-8. Available from: https://doi.org/10.1093/bja/54.3.313

15. Prasad A. Roux-en-Y gastric bypass vs intensive medical management for the control of type 2 diabetes, hypertension, and hyperlipidemia. Apollo Medicine [Internet]. Medknow; 2013 Dec;10(4):3246. Available from: https://doi.org/10.1016/j.apme.2013.10.010

16. Akhmad Fithrah B, Fuadi I, Rahardjo S, Bisri T, et al. Tatalaksana Anestesi pada Bedah Minimal Invasif Deep Brain Stimulation (DBS). Jurnal Neuroanestesi Indonesia [Internet]. Indonesia Society of Neuroanesthesia and Critical Care (INA-SNACC); 2017;6(2):11423. Available from: https://doi.org/10.24244/jni.vol6no2.137

17. Butterworth JF, Mackey DC, Wasnick JD. Morgan and Mikhail's Clinical Anesthesiology. 6th ed. New York: McGraw-Hill Education; 2018.

18. Lalmand M, Wilwerth M, Fils J-F, Van der Linden P. Continuous Ropivacaine Subfascial Wound Infusion Compared With Intrathecal Morphine for Postcesarean Analgesia. Anesthesia \& Analgesia [Internet]. Ovid Technologies (Wolters Kluwer Health); 2017 Sep;125(3):907-12. Available from: https://doi.org/10.1213/ ane.0000000000001892

19. Tan P-H, Chia Y-Y, Lo Y, Liu K, Yang L-C, Lee T-H. Intrathecal bupivacaine with morphine or neostigmine for postoperative analgesia after total knee replacement surgery. Canadian Journal of Anesthesia/ Journal canadien d'anesth sie [Internet]. Springer Science and Business Media LLC; 2001 Jun;48(6):551-6. Available from: https://doi. org/10.1007/bf03016831

20. Gunawan SG. Farmakologi dan Terapi. 5th ed. Jakarta: Departemen Farmakologi dan Terapeutik; 2017.

21. Falcão LFR, Perez MV, De Castro I, Yamashita AM, Tardelli MA, Amaral JLG. Minimum Effective Volume of 0.5\% Bupivacaine With Epinephrine in Ultrasound-Guided Interscalene Brachial Plexus Block. Survey of Anesthesiology [Internet]. Ovid Technologies (Wolters Kluwer Health); 2013 Oct;57(5):254-5. Available from: https://doi. org/10.1097/01.sa.0000433204.09568.0b

22. Fournier R, Van Gessel E, Weber A, Gamulin Z. Epinephrine and clonidine do not improve intrathecal sufentanil analgesia after total hip replacement $\uparrow$. British Journal of Anaesthesia [Internet]. Elsevier BV; 2002 Oct;89(4):562-6. Available from: https://doi. org/10.1093/bja/aef222

23. Pendit BU, Yesdelita N. Fisiologi Manusia Dari Sel ke Sistem. 6th ed. Jakarta: Penerbit buku kedokteran; 2009.

24. Hall J. Guyton dan Hall Buku Ajar Fisiologi Kedokteran. 12th ed. Jakarta: Elsevier (Singapore) Pte Ltd ; 2014.

25. Setiyohadi B, Mulansari NA, Sukmana N. Reduced bone mineral density and serum C-telopeptide concentration in HIV-infected patients in Cipto Mangunkusumo Hospital. Acta Med Indones. 2009 Oct;41(4):191-4. 
26. Turk DC, Okifuji A. Psychological Factors in Chronic Pain: Evolution and Revolution. Journal of Consulting and Clinical Psychology. 2002;70(3):678-90.

27. Ardinata D. Multidimensional nyeri. Jurnal Keperawatan Rufaidah Sumatera Utara. 2007;2(2):77-81.

28. Sylvia PA, Wilson LM. Patofisiologi : Konsep klinis proses-proses penyakit bagian. 4th ed. Jakarta: EGC; 2005. (1).

29. Bupivacaine/fentanyl/morphine. Reactions Weekly [Internet]. Springer Nature; 2017 Jan;1633(1):147-147. Available from: https://doi.org/10.1007/s40278-017-24417-8
30. Boulton A, Carter-Thomas S, Rowley-Jolivet E. Issues in corpus-informed research and learning in ESP. Corpus-Informed Research and Learning in ESP [Internet]. John Benjamins Publishing Company; 2012;1-14. Available from: https://doi.org/10.1075/scl.52. 01 bou

31. Lewis JW, Talkington WJ, Tallaksen KC, Frum CA. Auditory object salience: human cortical processing of non-biological action sounds and their acoustic signal attributes. Frontiers in Systems Neuroscience [Internet]. Frontiers Media SA; 2012;6. Available from: https://doi.org/10.3389/fnsys.2012.00027

Різниця тривалості між анальгезією бупівакаїну гіпербаричним морфіном і бупівакаїну гіпербаричним адреналіном інтратекально до постопераційних періодів кесарського розтину в лікарні Бхаянкара Матарам

Erwin Kresnoadi

Медичний факультет, Університет Діпонегоро, Індонезія

Анотація. Передумови та завдання: Найбільш використовуваною регіонарною анестезіологічною технікою $\epsilon$ спінальна анестезія. Спинномозкова анестезія - це легша техніка для досягнення глибини та швидкості блокади нервів. Деякі ліки можуть бути використані в якості ад’юванта місцевої анестезії для підвищення ефекту аналгезії бупівакаїну. Дане дослідження спрямоване на порівняння ефективності введення 0,1 мг інтратекально морфіну і 0,1 мг інтратекально адреналіну для продовження 0,5\% 12,5 мг гіпербаричної аналгезії бупівакаїну до постопераційних періодів кесарського розтину. Метод: Дане дослідження є експериментальним клінічним дослідженням рандомізованої подвійної сліпої фази II. Предметом даного дослідження є пацієнти з планової хірургії (АSA I і II) із спінальною анестезією віком 18-40 років, вагою близько $50-70$ кг. $€ 48$ пацієнтів, які розділені на 2 групи; 24 пацієнти групи М (морфін 0,1 мг) і 24 пацієнти групи Е (адреналін 0,1 мг). Результат: Результат цзього дослідження показав, щзо тривалість аналгезії більша у групі М (морфін 0,1 мг), ніж у групі T (трамадол 25 мг) (309,08 \pm 5,55 проти 221,66 — 6,43). Висновок: ад’ювант 0,1 мг морфіну і 0,5\% 12,5 інтратекального гіпербаричного бупівакаїну може збільшити тривалість робочого періоду знеболювання після операції кесарського розтину краще, ніж 0,5\% 12,5 мг бупівакаїну та 0,1 інтратекально адреналіну.

Ключові слова: спинномозкова анестезія, бупівакаїн, тривалість аналгезіі, морфін, адреналін

Разница продолжительности между анальгезией бупивакаина гипербарической морфином и бупивакаина гипербарически адреналином интратекально к постоперационным периодам кесарева сечения в больнице Бхаянкара Матарам

Erwin Kresnoadi

Медицинский факультет, Университет Дипонегоро, Индонезия

Аннотация. Предпосылки и задачи: Наиболее используемой регионарной анестезиологической техникой является спинальная анестезия. Спинномозговая анестезия - это более простая техника для получения глубины и скорости блокады нервов. Некоторые лекарства могут быть использованы в качестве адъюванта местной анестезии для повышения эффекта анальгезии бупивакаина. Данное исследование направлено на сравнение эффективности введения 0,1 мг интратекально морфина и 0,1 м2 интратекально адреналина для продолжения 0,5\% 12,5 м2 гипербарической аналгезии бупивакаина к постоперациионным периодам кесарева сечения. Метод: Данное исследование является экспериментальным клиническим исследованием рандомизированной двойной слепой фазы II. Предметом данного исследования являются пац̧иенты плановой хирургии (АSA I и II) со спинальной анестезией в возрасте 18-40 лет, весом около 50-70 кг. Дано 48 пацииентов, которые разделены на 2 группы; 24 пацииента группы М (морфин 0,1 мг) и 24 пацииента группы Е (адреналин 0,1 мг). Результат: Результат этого исследования показал, что продолжительность аналгезии больще в группе М (морфин 0,1 мг), чем в группе Т (трамадол

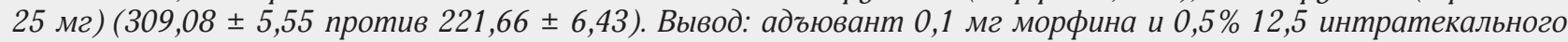
гипербарического бупивакаина может увеличить продолжительность рабочего периода обезболивания после операции кесарева сечения больше, чем 0,5\% 12,5 мг бупивакаина и 0,1 интратекально адреналина.

Ключевые слова: спинномозговая анестезия, бупивакаин, продолжительность аналгезии, морфин, адреналин. 